\title{
M. Nel
}

\section{EUNUG IN DIE ANTIEKE NABYE OOSTE}

\author{
ABSTRACT
}

\section{EUNUCH IN THE ANCIENT NEAR EAST}

The Bible uses the term "eunuch" several times. The question arises as to the meaning of this term. In this article Biblical and extra-Biblical data are considered. It is argued that the Hebrew word, סריס, refers to a castrated man, and that, in biblical usage, it refers to a castrated man in terms of Israel's religion (Deut. 23:1; Is. 56:3). The term is used in a different sense when it refers to a foreign person, i.e. a person in an official capacity in a king's court (as in Gen. 37), or a military commander (as in 1 Kings 22:9; 2 Kings $8: 7 ; 23: 12 ; 25 ; 19$; Jer. 52:25). The reference to the Ethiopian eunuch in Acts 8 is also discussed, and the conclusion is drawn that סריס refers to a foreign official visiting Jerusalem to worship, and not to a castrated man.

\section{INLEIDING}

In die antieke Nabye Ooste het die eunug 'n belangrike rol gespeel. Die doel van hierdie artikel is om Bybelse en buite-Bybelse gegewens te bespreek om te bepaal wie en wat die eunug was.

Die Hebreeuse selfstandige naamwoord סרים kom van die werkwoord "om te ontman, kastreer" (Gesenius 1953:710). Die woord het egter 'n gespesialiseerde betekenis verkry, net soos met "seun van die koning" as titel vir 'n hofamptenaar of hoë militêre offisier gebeur het (Gesenius 1953:710; Holladay 1971:260). Die primêre betekenis was "hofamptenaar", met as newebetekenis "gekastreerde" of "eunug". Herodotus (viii.105) meld dat die eunug dikwels deur regeerders in die Ooste in diens geneem is en hoog geag is omdat hulle in alle opsigte betroubaar was. Hulle is dikwels aan die hoof van koninklike huishoudings gestel.

'n Eunug is 'n persoon (gewoonlik'n man) waarvan die testis, en soms ook die penis en skrotum, vernietig of verwyder is. Dit lei tot steriliteit en tot onderskeie grade van impotensie en verlies aan geslagsdrange. In die geval van prepubertale kastrasie ontwikkel die persoon eunochoïede afwesige seksuele 
kenmerke en impotensie. Kastrasie ná puberteit lei tot steriliteit en mettertyd tot impotensie asook vermindering van aggressie. Ontmanning word beleef as vernedering en verwerping deur die gemeenskap (Retief, Riekert \& Cilliers 2002:115).

In die Ou Testament is dit dikwels baie moeilik om uit die konteks te bepaal na watter van die betekenisse verwys word. Potifar is volgens Genesis 39:1 getroud en 'n סריס. Die beste vertaling sou dus "hofamptenaar" wees. Die Septuagint vertaal egter die woord as $\epsilon \dot{v}$ ov̂Xos. In Jesaja 56:3 is die verwysing duidelik na "gekastreerde". In Nehemia 1:11 het sommige kopieë van die Septuagint

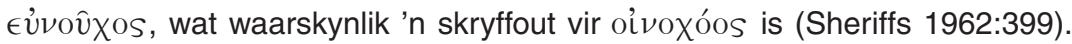
Josefus (Ant. X.10.1) meen dat Daniël en sy drie vriende gekastreerdes was. Die verwysing in Daniël 1:4 dui egter op die teenoorgestelde.

Volgens die ou Testament mag 'n gekastreerde nie deel vorm van die byeenkoms wat voor JHWH vergader nie (Deut. 23:1). ${ }^{1}$ Die teenoorgestelde lees 'n mens egter in Jesaja 56:3: dat die ontmande nie moet dink dat hy 'n droë boom is nie. Uit die verband is dit duidelik dat na 'n gekastreerde verwys word.

In die Nuwe Testament kom die woord $\epsilon$ v่voûXos voor, wat moontlik af-

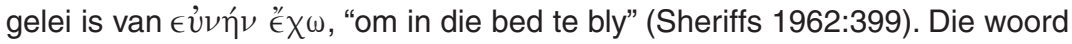
verwys egter nie noodwendig na 'n eunug nie. In Handelinge 8:27 verwys dit moontlik na beide, terwyl dit in Matteus 19:12 definitief na "gekastreerde" verwys. Dié teks verwys na drie klasse van eunugs: gebore eunugs, mensgemaakte eunugs en die eunugs wat vir geestelike redes kies om so te wees (ter wille van die koninkryk van die hemel). Origenes het dié gedeelte letterlik opgeneem en homself ontman.

Judaïsme ken slegs twee klasse van eunugs: mans wat ontman is, en mans wat van nature so gebore is, of "eunugs van die son", omdat sulke persoon 'n eunug is vandat hy die son die eerste keer gesien het (Misjna Zab. ii.1) (Sheriffs 1962:399).

\section{DIE MILITÊRE ORGANISASIE IN MESOPOTAMIË}

Die eunug het veral in Antieke Midde-Oosterse militêre en hofstrukture 'n belangrike rol gespeel. Heelwat is bekend van die organisasie van die Mesopotamiese hof en weermag uit monumente en tekste van Sumeriese stadstate wat bewaar gebly het uit die periode van die derde millennium v.C. ${ }^{2}$ In dié periode

1 In Deuteronomium 23:1 (NAV, 23:2) kom die term סריס nie voor nie alhoewel die skrywer streng afkeurend na kastrasie deur middel van vernietiging of uitsnyding van geslagsdele verwys (Retief, Riekert \& Cilliers 2002:116).

2 Vgl. Schroeder (1920:155-158); Saggs (1963:145-154); Salonen (1965); Reade (1972:87-112); Postgate (1974; 1979:193-221); Parpola (1981:117-134); Houwink ten Cate (1983:91-109) en Brenjes (1986:133-142). 
het die Assiriërs die toneel oorheers. Hierna het die Babiloniese mag opgetree voordat dit geswig het voor die aanslag van die Perse aan die einde van die eerste helfte van die eerste millennium.

Die weermag het die vyandigheid tussen die Sumeriese state, Assirië en Babilonië gedryf. Dié state het ook verskeie magtige bure gehad wat hulle met tye bedreig het - Elam, Egipte, die Hetiete, Mitanniane, Urartu en Sirië. Verskeie golwe invallers het ook met tye oor die Vrugbare Halfmaan gespoel die Guti, Seevolke en Suteane (Watkins 1983:100-102). Die gevolge hiervan was dat Mesopotamiese weermagte verskeie militêre tegnieke en toerusting ontwikkel het, en dat die weermagpersoneel se hiërargie ook uitgebrei is. ${ }^{3}$

Aanvanklik was die Sumeriese weermagte se getalle beperk. 'n Teks uit die helfte van die derde millennium beskryf die opgekommandeerde dienspligtiges as 182 mans uit Uruk; 192 uit Adab; 94 van Nippur; 60 van Lagas; 56 van Suruppak en 86 van Umma, wat 'n totaal van 670 vorm. Wanneer Sargon aan bewind kom, vergroot hy sy weermag sodat hy Sirië met 5400 soldate aanval. Sy seun Rimus neem 5700 Sumeriërs gevange wat teen hom in opstand kom. Die weermag is versterk deur gevangenes, veral Elamiete, Siriërs en Arabiere, te gebruik. Wanneer Shamshi-Adad (1814-1782 v.C.) Nurrugum beleër, gebruik hy 60000 soldate (Goetze 1963:128).

Vanaf die sewentiende eeu veroorsaak die uitvinding van die oorlogswa 'n rewolusie in die kuns van oorlogvoering. Die wa was lig, met twee wiele, met vier, ses of agt speke, en kon vinnige maneuvers op die oorlogsveld uithaal. ${ }^{4}$ Die bemanning van die strydwa (rākib narkabtı) was die kizû of aanvoerder, met elke tien strydwaens onder aanvoering van die emantuhlu. Elke vyftig strydwaens was onder bevel van die bevelvoerder-oor-vyftig, die rab hanša. 'n Senior offisier van die koninklike hof, die šākin biti, was in beheer van die bewaring van strydwaens, en opleiding van personeel. In baie gevalle het 50 soldate ook die basis vir die opdeling in eenhede gevorm (Salonen 1968:160-162).

Die infanterie ( $z \bar{u} k u)$ was die essensiële element van die weermag, en was effektief in beleërings asook operasies in die bergagtige gebiede buite Mesopotamië, waar strydwaens nie kon beweeg nie. Die infanterie het bestaan uit soldate wat spiese dra (swaar infanterie) en soldate met pyl-en-boog asook slingervelle (ligte infanterie). Dan was daar ook die sappeurs, die şab hupši. Die kitkittû se

3 Vir 'n bespreking van die Mesopotamiese weermagte asook die organisering van magte onder ander tydgenootlike state, vergelyk Bonnet (1926); Evans (1960); Goetze (1963); Von Soden (1963); Yadin (1963); Rainey (1965); Salonen (1965 \& 1968); Sasson (1969); Herzog \& Gichon (1978); Eichler (1983); Eph'al (1983); Houwink ten Cate (1983); Watkins (1983); Dalley \& Postgate (1984); Dalley (1985) en Brenjes (1986).

$4 \quad$ Vir inligting oor die strydwa, vgl. Moortgat (1930:841-854); Nagel (1966); Littauer (1976:217-226); Littauer \& Crouwel (1979). 
taak was om die vyand met byle en swaarde aan te val (Eichler 1983:95-102; Miller, McEwen \& Bergman 1986:178-195).

Akkadiese tekste verwys selde na die rol wat die vloot in oorlogvoering gespeel het (vgl. De Graeve 1981). Net so word gevalle selde bespreek waar soldate gedros het of in opstand gekom het. Semi-nomades wat soms tydelik in die weermag opgeneem is, het wel by geleentheid hulle kennis van die gebied gebruik om te ontsnap.

Die soldaat was in 'n posisie waar hy geen juridiese status gehad het nie, wat ook van slawe die geval was. Hy moes homself verryk deur buit te steel of die plaaslike bevolking uit te buit (Matthews 1981:135-151).

Die hiërargie van die weermag het duidelik tussen hoër en laer range onderskei. Die militêre titels wat gebruik is, was gebaseer op die hoeveelheid manne waaroor bevel gevoer word (rab hanšu was 'n bevelvoerder-oor-vyftig en rab l'lim was bevelvoer-oor-duisend) of die aard van die troepe (rab kalle was leier van die versendingsbeamptes; rab raksu leier van die berede boodskappers; rab kallāpāni die leier van die sappeurs; rab dayyali die leier van die verkenners; rab urâte leier van die wapenrusting; rēš narkabti die meester van die strydwaens; rab mudi ša pethalli die kavallerie-bevelvoerder; en rab mugi ša narkabti die strydwa-bevelvoerder). Die mušarkisu was in beheer van al dié poste (Rainey 1965:17-27; Young 1983:19-23). Die poste het nie dieselfde belangrikheid in die verskillende vertakkings van die weermag gehad nie. Die offisiere van die kavallerie en strydwa-mag was dikwels ryk en magtig, en het belangrike beheerposte gevul.

Die wag ( $k i s ̧ i r$ šarrutt) het bestaan uit die elite troepe van die weermag, en hulle kapteins (rab kişir) is deur die koning self aangestel (Evans 1960:34-36).

Die Assiriese weermag is georganiseer in provinsiale eenhede. Sommige was direk afhanklik van die koning (ša qurbuti) en onder sy bevel, terwyl ander afhanklik was van die paleis onder bevel van die groot eunug ( $r a b$ ša rēšl) (Vgl. Dalley \& Postgate 1984; Dalley 1985). Dit is duidelik dat dié posbenaming niks te doen gehad het met die wortelbetekenis van "eunug", as ontmande nie.

Die staf het bestaan uit die grotes van die ryk. Sedert die tweede helfte van die agste eeu het dit bestaan uit die turtānu, twee bevelgeneraals, een "aan die linkerkant" en een "aan die regterkant". Die "boodskapper van die paleis" of nāgir ekalli, die "groot hofmeester" of rab šāqê en die "groot senior offisier" (abarakku of rabŭ) het almal ook militêre verantwoordelikhede gehad. Die koning was die hoof van die weermag en het in meeste gevalle die belangrikste veldtogte gelei. Soms het hy sy mag aan 'n generaal afgestaan wat namens hom 'n veldtog gelei het.

Die gevaar verbonde aan die sentralisering van gesag in die weermag het duidelik geblyk in die val van die Assiriese ryk in 610 v.C., asook die Babiloniese 
mag in 539 v.C. voor die Perse. In albei gevalle is die koning se mag geneutraliseer, sodat die weermag kohesie en effektiwiteit verloor het.

\section{BYBELSE EN BUITE-BYBELSE VERWYSINGS NA EUNUG}

Verskeie verwysings kom in die Bybel voor na persone en die instelling van die pos, wat kortliks bespreek word.

\subsection{Potifar}

Genesis 37:36 vermeld dat die Midianiete Josef in Egipte aan Potifar verkoop het. Potifar word beskryf as פוטיפר סריס פרעה שר הטבחים. In Genesis 39:1 word die volgende beskrywing gegee: פוטיפר סריס פרעה שר הטבחים איש פרער. Die eienaam Potifar kom wyd voor vanaf die tiende eeu tot in Romeinse tye, en beteken "hy-vir-wie-(die songod) Re-gee". Josef se latere skoonpa, Potifera, se naam is nader aan die oorspronklike Egiptiese oorspronklike (Schulman 1975:235-243). Potifar word beskryf as 'n eunug in die Farao se diens, 'n kaptein van die slagters ("slagters" het waarskynlik mettertyd van betekenis verander en na die koninklike wag verwys; geen verdere Egiptiese verwysings is gevind nie). Dat Potifar nie 'n eunug was nie, is duidelik uit die feit dat hy getroud was en moontlik selfs 'n dogter gehad het (Gen. 41:45; Retief, Riekert \& Cilliers 2002:118). Die enigste ander Egiptiese verwysings na "eunug" dateer uit die periode van Persiese dominasie, in die vyfde eeu v.C. (Kadish 1969:55-62).

\subsection{Rabsaris}

Die rabsaris of רב־סריס (Akk. rab-ša-rēšl) was 'n Assiriese amptenaar met 'n hoë rang. In Assiries beteken die woord "hoof-eunug". Soos reeds vermeld (by 2), vorm die eunug 'n belangrike deel van die Assiriese burokrasie. Dokumente dui aan dat talle mense dié ampsbenaming gehad het (Reade1972:16). Die rabsaris, saam met die rabsake en die tartan, speel 'n belangrike rol in die beleëring van Jerusalem deur Sanherib (beskryf in 2 Kon. 18:17; Retief, Riekert \& Cilliers 2002:119). Rabsaris was ook die titel van 'n amptenaar met 'n hoë rang in die Babiloniese weermag, en so 'n amptenaar het saam met die rabsag 'n leidende rol in die Babiloniese beleg van Jerusalem deur Nebukadnesar II in 587 v.C. gespeel (soos opgeteken in Jer. 39:3, 13). 


\subsection{Hatak}

Hatak is die eunug wat deur koning Ahasveros aangestel is om koningin Ester te bedien, volgens Ester 4:5-12. Ester stuur Hatak na Mordegai wanneer sy hoor hoe hy optree nadat die nuus van Haman se dekreet bekend geword het. Mordegai verduidelik aan die eunug wat die rede vir sy optrede is, en versoek Ester om dringend vir haar volk in te tree. Die eunug is duidelik in 'n vertrouensposisie. Die Targum beskryf die uitkoms wat vir die Jode aanbreek as soortgelyk aan dié wat Daniël vir sy volk gebring het, en Hatak word as Daniël beskryf (Grossfeld 1984:87). Haupt (1982:43) verwys na die Joodse tradisie dat die eunug van Joodse afkoms sou wees. Sy naam het egter 'n Persiese oorsprong en beteken "die goeie een" of "boodskapper" (Gehman 1924:324).

\subsection{Mehuman, Bisseta, Garbona, Bigta, Abagta, Setar en Karkas}

Die sewe eunugs van koning Ahasveros word in Ester 1:10 gelys. Dat daar sewe eunugs was, reflekteer moontlik Persiese mitologie dat die hemelse koninklike hof sewe ministers het (Moore 1992:641). Die orde waarin die name voorkom, dui moontlik op die belangrikheid van hulle poste. Hulle pos word beskryf as dat hulle voor die koning gedien het: הסריסים המשרתים את־פני המלך אחשורוש.

Hulle is kamerhere vir die koning, en roep individue wat deur die koning gespreek word. Hulle probeer om koningin Vasti na die koning se banket te bring (Est. 1:10-12), en moontlik is dit ook hulle wat Haman gaan haal om die twee bankette saam met die koning by Ester te geniet (Est. 5:5; 6:14). Hulle begelei ook moontlik veroordeelde misdadigers na hulle teregstelling, soos Ester 7:9-10 suggereer. Hulle het nie noodwendig enige direkte verbintenis met die koning se harem nie, en daarom is die term "eunug" simbolies (Weidner 1956:259). ${ }^{5}$ Hulle name is, met een uitsondering (Karkas, van Avestaanse kahrkâsa, aasvoël), van Persiese oorsprong. Millard (1977:482-484) lei hieruit af dat die outeur van die Esterboek sy verhaal van 'n historiese weergawe aflei, of ten minste goeie kennis van Persiese name en gebruike het.

\subsection{Aspenas}

Sadrag, Mesag en Abednego is die Babiloniese name wat Nebukadnesar se hoof-eunug, Aspenas, vir die drie Joodse jongmanne gee in die ballingskapsperiode, volgens Daniël 1:7. Daniël kry ook'n Babiloniese naam, Beltsasar. Dié vier is die helde van die verhale in die eerste helfte van die Daniëlboek. Aspenas

5 Die NAV verwys na hulle as "paleisbeamptes", soos die KJV se "chamberlains". 
word ses keer beskryf as die שר הסריסים, die leier of prins van die eunugs (Dan. $1: 3,7)$. Daar is geen rede om te dink dat Aspenas, of die vier Joodse jongmanne, gekastreerdes was nie. Die beskrywende titel dui eerder op 'n funksionaris van die koninklike hof. Die Griekse weergawes van Theodotion gee Aspenas se naam as Ashpenaz (getranslitereerd) weer, terwyl die Septuagint 'n nuwe naam, Abiesdri, uitdink, gebaseer op die verkeerde interpretasie van die titel "hoofpaleisbeampte" in Daniël 1:11. Die verandering van die Joodse na Babiloniese name is gebruiklik aan die antieke Nabye Ooste, en dui op 'n verandering in die lotsbestemming van die mens (nomen est omen) (Bar-Efrat 1989:40). Dieselfde gebeur met Josef wat deur die Farao hernoem word (Gen. 41:45) en Nebukadnesar wat in 2 Konings 24:17 Mattanja se naam na Sedekia verander. Die interessante is dat, literêr gesproke, die Hebreeuse name en Babiloniese eweknieë nie blindweg in die teks weergegee word nie. Die name word daarenteen subtiel in die teks ingeweef met die doel om die kulturele en religieuse ondertone te reflekteer wat tussen die Joodse ballinge en hulle Babiloniese oorheersers bestaan (Coxon 1992:491). So kom die Babiloniese weergawe van die name dertien keer binne negentien verse in Daniël 3 voor (in vv. 12, 13, 16, 19, 20, 22, 23, 26 [twee maal], 28, 29, 30). Die klankryke herhaling lyk bloot retories van aard, maar speel binne die konteks van die konfrontasie tussen die Joodse helde en Nebukadnesar 'n belangrike rol. Die koning gebruik die name vyf keer (in vv. 14, 16, 18, 28 en 29). So verskaf Babiloniese naamgewing 'n outentieke lokale kleur aan die narratiewe terwyl dit terselfdertyd Babiloniese kulturele waardes satiriseer.

\subsection{Bagoas}

Bagoas is die eunug in beheer van Holofernes se persoonlike sake, volgens Judit 12:11. Die eienaam is Persies van oorsprong, en volgens Plinius ( $H N 13.41)$ is dit ' $n$ gewilde naam vir eunugs. Die afleiding is dat die naam moontlik as ' $n$ titel gebruik word eerder as vir 'n persoonlike naam. Die naam kom ook in ander bronne voor: Josefus (Ant 11.7.1) verwys na 'n Bagoas wat 'n generaal in Artaxerxes II Mnemon se leër was, en later die goewerneur van Jerusalem geword het. Diodorus Sikulus (Hist 311.19.2-3; 16.47.4) beskryf 'n Bagoas wat adviseur vir Artaxerxes II Ochus was in sy veldtog teen Fenisië en Egipte. In die Elefantini-papirus \#30 (CAP) kom Bagoas in Aramese vorm voor as baggōhî, wat die goewerneur van Jerusalem was. Enigeen van dié persone kan verwys na die dienskneg van Holofernes wat deur die boek van Judit Bagoas genoem word. 


\subsection{Post-eksiliese Judese amptenare}

Ná-eksiliese Judese amptenare se titels het verander van dié van amptenare in voor-eksiliese stede en dorpe. Dit mag deels te doen hê daarmee dat Persiese gebruike in die tyd van Darius I oorgeneem is, of in navolging van Xerxes se administratiewe herorganisering, ná die Babiloniese en Egiptiese opstande met sy troonopvolging. In die koningstyd is die hoogste amptenaar die šar, afgelei van die Akkadiese šarru, koning. In Bybelse Hebreeus het die term verskeie betekenisse, alhoewel dit nie na so 'n hoë amp soos in die Akkadiese wêreld verwys nie. Dit verwys na die hoogste amptenare van Dawid (2 Kron. 22:17) en Salomo (1 Kon. 4:2); prinse (Pred. 10:16; Hos. 3:4); magistrate (Jes. 1:23); en die stadsregeerder of burgemeester (Rig. 9:30; Jos. 12:9-24; 1 Kon. 22:26 $=2$ Kron. 18:25).

Saam met die šar is die pāqid en nāgid asook raadgewers en polisie (šōmēr) (Boer 1955:42-71; Betylon 1986:633-642). In dié verband kom sāris voor, afgelei van die Akkadiese ša rēsî, "hy wat die leier is", as aanduiding van 'n amptenaar verbonde aan die koninklike hof. Wanneer dit verwys na 'n buitelandse pos, is die posvlak veel hoër - Genesis 37-38 en Ester 1:10-11 verwys na iemand wat in 'n vertrouensverhouding met die koning staan. Vergelyk ook die verwysings in 1 Konings 22:9; 2 Konings 8:7; 23:12; 25:19 en Jeremia 52:25.

In navolging van dié gebruik is Nehemia se posvlak ook hoog. Of Nehemia 'n gekastreerde was (Neh. 1:11 praat van משקה למלך) soos sommige Griekse weergawe meen ( $\epsilon \dot{v} \nu$ ov̂Xos, wat ook in 2 Esras 11:11 gebruik word), is te betwyfel (Yamauchi 1980:132-142). Die konteks suggereer eerder 'n administratiewe pos. Die betekenis van Bybelse terme vir Judese amptenare het dus mettertyd verskuif.

\subsection{Die Boek van Agikar}

Agikar is bekend as 'n Assiriese wyse wat die held van die boek is wat deur Jode van ouds af gelees en bewaar is (Van der Toorn 2002:52). Verskeie weergawes van dié werk is oorgelewer. Agikar was waarskynlik nie 'n historiese figuur nie. Onlangs is egter gevind dat daar' $n$ Assiriese geleerde met dié naam in die tyd van Esarhaddon (680-669 v.C.) geleef en gewerk het (Paul 2002:67). Die naam beteken "my broer is waardevol".

Die vroegste weergawe van die boek dateer uit die laat vyfde eeu, in 'n papirus van Elefantini, as 'n gefragmenteerde Aramese teks wat Agikar beskryf: Hy het die seël van Sanherib bewaar, was die vader van die hele Assirië, en koning Sanherib en die hele Assiriese leër het op sy raad staat gemaak. Ook in Esarhaddon se tyd het hy dié pos beklee, en Esarhaddon noem hom 'n wyse skrywer, die raadgewer vir die hele Assirië (Niditch \& Doran 1977:179-193). 
Agikar het nie 'n seun van sy eie nie, en hy neem sy nefie Nadin aan, en leer hom wysheid met die doel dat Nadin sy pos kan oorneem. Die nefie is egter 'n niksnuts wat sy oom ondermyn. Hy oortuig Esarhaddon dat sy oom tereggestel moet word. Latere tekste toon hoe Nadin sy oom se korrespondensie vervals om te bewys dat sy oom verraad teen die koning pleeg. Die koning vaardig 'n amptenaar met die naam Namushumishkun af om Agikar dood te maak, maar die wyse ou man herinner hom daaraan hoe hy in ander omstandighede die amptenaar se lewe gered het. Namushumishkun maak dan 'n eunug in Agikar se plek dood, en steek die wyse man in sy eie huis weg. Die Aramese narratief eindig hier. Die teks verraai dat die eunug se lewe as minderwaardig beskou word teenoor die van die wyse Agikar. Dat 'n eunug vir hierdie doel afgesonder word, het moontlik daarmee te doen dat in die wêreld waarbinne die teks ontstaan het, op die eunug neergesien is, wat dan op die betekenis dui dat dit 'n ontmande of gekastreerde was.

In Siriese, Armeniese en Arabiese weergawes gaan die verhaal voort om te vertel hoe Esarhaddon kort hierna Agikar se wysheid nodig kry as die Egiptiese koning hom uitdaag om 'n paleis tussen hemel en aarde te bou. Die Egiptiese koning het natuurlik te hore gekom dat Agikar dood is, en dat die Assiriese koning sonder hom min kan doen. As die Assiriese koning die uitdaging aanvaar, kan hy Egipte se staatsinkomste vir drie jaar lank kry. En as hy nie kan nie, ontvang Egipte graag vir drie jaar lank Assiriese staatsinkomste. Terwyl Esarhaddon met sy hande in sy hare sit, vertel die offisier hom dat Agikar nog leef. Hy word dadelik na Egipte gestuur waar hy die uitdaging suksesvol aanvaar. Hy kom met geweldige rykdomme terug en straf sy nefie; Nadin sterf uiteindelik aan sy wonde (Paul 2002:67).

Die Agikar-papirus is by die Joodse militêre kolonie van Elefantini gevind, maar niks in die teks suggereer Joodse outeurskap nie. Geen Joodse invloede kom ook daarin voor nie. In die Deutero-kanonieke boek van Tobit word Agikar egter verander van 'n Assiriër na 'n Israeliet uit die stam van Naftali, wat 'n familielid van Tobit is. Die boek Tobit dateer moontlik uit die derde eeu v.C. (Doran 1986:299). Verskeie ooreenkomste met die boek van Agikar kom hierin voor (Greenfield 1981:329-336). Beide speel in Assirie af, in die tyd dat Assiriese konings Samaria verwoes en die Noordryk in ballingskap wegvoer. Beide is wysheidsgeskrifte met goeie raad deur 'n wyse ou man aan sy seun. Tobit noem Agikar in vier gedeeltes in sy boek. Agikar is die seun van sy broer wat verantwoordelik was om toesig oor die Assiriese ryk se finansies te hou. As Tobit blind word, sorg Agikar twee jaar lank vir hom. Tobit verwys ook na Nadab (= Nadin), Agikar se nefie (Kodeks Sinaïtikus noem hom Agikar se nefie, terwyl Kodeks Vatikanus en Alexandrinus hom die nefie van Agikar en Tobit noem). In Tobit 14:10 gebruik Tobit die voorbeeld van Nadab en Agikar om sy raad in te klee. 


\subsection{Die Wysheid van Salomo}

Die Wysheid van Salomo is bedoel om lesers aan te moedig om in hulle soeke na wysheid te volhard. Die boek is in Grieks geskryf deur'n gehelleniseerde Jood van Aleksandrië, ná die stad deur Rome in 30 v.C. oorgeneem is. Op daardie stadium het die matelose waardering en bewondering vir Griekse sosiale en kulturele gebruike plek gemaak vir ontnugtering en teleurstelling. Waar PseudoAristeas die heidense kultus kritiseer, val Wysheid dit met wraakgierigheid aan, en verwys na die ontelbare misdade en korrupsie verbonde aan heidense afgodediens. Die boek bestaan uit drie dele: Wysheid se geskenk van onsterflikheid in 1:1-6:21; die aard en mag van wysheid en Salomo se soeke daarna (6:22-10:21); en goddelike wysheid of geregtigheid in Eksodus (11-19), met twee ekskurse, oor goddelike genade (11:15-12:22) en afgodediens (13-15) (Reese 1965:391-399).

Die eerste deel begin met ' $n$ oproep aan aardse heersers om geregtigheid of wysheid na te jaag, terwyl gesê word dat die heersers wat hulle nie hieraan steur nie, bestem is vir vernietiging. Vervolgens probeer die skrywer om die paradokse op te los wat rondom die onderwerpe van goddelike beloning en straf bestaan. Dat die regverdige ly en sterf, sê die skrywer, is slegs kort episodes van beproewing in die onsterflike bestemming van mense wat regverdig lewe. Dié pad bring hulle mettertyd uit by vrede, verheerliking en heerskappy oor die nasies, en 'n spesiale goddelike verligting (3:1-12). Die kinderlose vrou wie se lewe rein was, sal dan baie kinders hê. En die regverdige eunug sal 'n aandeel of porsie in die tempel van die Here kry (vgl. hierteenoor Deut. 23:1). Kinders wat egter uit onwettige geslagsgemeenskap gebore is, sal afgesny word. Kinderloosheid is te verkiese hierteenoor, mits dit gepaard gaan met deug (3:13-4:6). Vroeë dood is 'n noodsaaklike euwel omdat dit moontlik kan dui daarop dat die persoon vroeg verwyder word deur goddelike voorsienigheid om hom/haar te beskerm. Ware lewenslengte moet nie gemeet word aan chronologiese jare op aarde nie, maar in terme van die verkryging van wysheid (4:7-20). Die gedeelte sluit af deur te verwys na die uiteindelike regverdiging van regverdiges deurdat hulle na die hemel verhoog word om tussen die engelskare te lewe, terwyl die bose mense uiteindelik berou sal toon as hulle onder die besef kom van die dwaasheid waarin hulle geleef het (Zimmermann 1966:101-135).

Die verwysing na die eunug in dié boek, wat laat gedateer word, is duidelik na 'n ontmande. Die gevolgtrekking is dat die Griekse term op daardie stadium steeds vir "gekastreerde" gebruik is, alhoewel dit in die Septuagint dikwels gebruik word om na 'n militêre of administratiewe titel te verwys. 


\subsection{Etiopiese eunug}

Handelinge 8:26-40 vertel van die Etiopiese eunug wat deur die verkondiging van Filippus hom tot die Christelike geloof bekeer. Die karakter word beskryf

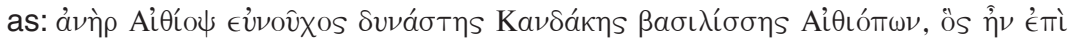

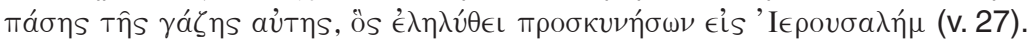

Die geografiese verwysing na "Etiopiër" verduidelik vir lesers dat die man van die gebiede ten suide van Egipte kom. Hy is ook 'n amptenaar van Kandake, wat vir eerste-eeuse lesers aandui dat hy verbind is aan die koninkryk van Meroe. Die koninginne van dié koninkryk is tradisioneel die kandake genoem. Dié gebied het bekend verwerf ná 'n Romeinse veldtog teen Meroe laat in die eerste eeu v.C., 'n wetenskaplike ekspedisie in 62 n.C., en 'n beplande militêre veldtog deur Nero wat nie uitgevoer is nie (Gaventa 1986:79).

Dat die Etiopiër as 'n eunug beskryf word, sou vir die eerste lesers 'n groter probleem skep. Die Etiopiër kon nie 'n proseliet van die Joodse godsdiens wees nie (vgl. Deut. 23:1 asook Josefus se Ant 4.290-291), alhoewel die teks aandui dat hy na Jerusalem gekom het om te aanbid, en die rol van Jesaja lees terwyl hy reis (Hand. 8:27-38). Nêrens lewer die Handelinge-skrywer kommentaar op die feit dat die eunug hom tot die Christelike godsdiens bekeer nie, terwyl eerste lesers sou verwag dat hulle Joodse skrywer bewus sou wees van die anomalie in terme van die Joodse godsdiens wat die eunug uit die tempel en tempeldiens uitsluit. Dit lyk asof die skrywer geen belang by dié aspek van sy verhaal het nie.

Soos reeds aangetoon, het die eunug dikwels 'n belangrike rol in Oosterse hofhoudings vervul, waar hulle in vertrouensposisies aangestel is. Moontlik is die skrywer se bedoeling om dié eunug slegs te koppel aan die titel van 'n belangrike koninklike amptenaar, sonder om enigsins die konnotasie te skep dat hy 'n ontmande sou wees. Die leser moet onder die indruk kom dat verwys word na iemand wat "van die eindes van die aarde af" kom, 'n ongewone en interessante persoon.

Die Boek van Agikar en Wysheid van Salomo toon albei aan dat "eunug" baie laat, in die inter-testamentêre periode, gebruik is vir 'n gekastreerde. Die Boek van Agikar is nie van Joodse oorsprong nie, terwyl die Wysheid van Salomo wel is. Die gevolgtrekking is dat "eunug" wel tot laat steeds vir "gekastreerde" gebruik is, naas die militêre en administratiewe gebruik daarvan in die wêreld buite die Jodedom.

Die Etiopiese man se aksies in die verhaal onderskryf die skrywer se tekening van hom as 'n interessante, romantiese en selfs eksotiese persoon. Die man is gereed vir wat volg omdat hy van Jerusalem kom waar hy in die tempel aanbid het en besig is om uit die Jesajarol te lees. Hy is aktief besig om hom voor te berei vir wat volg, teenoor Filippus wat byna passief reageer op die instruksies 
deur die Gees en die vrae wat die Etiopiese man aan hom stel. Die Etiopiër neem die inisiatief om Filippus te nooi om op die wa te klim, om vir hom die Jesajarol te interpreteer, te vra om gedoop te word en op sy weg te gaan terwyl hy vol vreugde is (vv. 31, 34, 36, 39) (Van Unnik 1973:328-339).

\section{SINTESE}

Die gegewens wat uit buite-Bybelse en Bybelse bronne oor "eunug" ondersoek is, dui aan dat die term 'n diversiteit van betekenisse en gebruike gehad het. Dit is gebruik om na ontmandes of gekastreerdes te verwys, terwyl dit terselfdertyd ook gebruik is (in Mesopotamiese dialekte, Aramees, Hebreeus en Grieks) om na 'n militêre offisier of administratiewe beampte verbonde aan die koninklike hofhouding te verwys. As konjektuur word aangebied dat die term aanvanklik vir gekastreerdes gebruik is, en dat die verbintenis met die koninklike hofhouding verband hou daarmee dat sulke persone in die harem van die koning diens gedoen het, waar hulle geen bedreiging vir die koning se vrouens ingehou het nie. Weldra het die pos ontwikkel sodat eunugs ook elders aangewend is, en mettertyd het dit gebeur dat die posbenaming gebruik is vir persone wat nie (noodwendig) ontman is nie.

In die Joodse geskrifte verwys die term na 'n ontmande (soos in Deut. 23:1, Jes. 56:3 en Matt. 19:12), behalwe wanneer dit gebruik word as titel en posbenaming vir ' $n$ buitelandse bevelvoerder. Dan verwys dit na iemand wat ' $\mathrm{n}$ militêre posisie beklee (soos in 1 en 2 Konings gebeur, asook in Jeremia), of iemand wat aan die koninklike hofhouding verbonde is (soos in Gen. 37 die geval is).

Die verwysing na die Etiopiese eunug is ook na iemand wat 'n pos aan 'n koninklike hof beklee, en verwys nie na 'n ontmande nie. Dit verduidelik hoekom die Handelinge-skrywer nie moeite doen om te verduidelik hoe dit kan gebeur dat 'n "eunug" in die Jerusalemtempel toegelaat word nie. 


\section{BIBLIOGRAFIE}

BAR-EFRAT, S. 1989. Narrative art in the Bible. Translated by D. Shefer-Vanson. Decatur: Almond Press.

BETYLON, J.W. 1986. The provincial government of Persian Period Judea and the Yehud Coins. Journal of Biblical Literature 105:633-642.

BOER, P.A.H.

1955. The counsellor. Vetus Testamentum Supplement 3:42-71.

BONNET, $\mathrm{H}$.

1926. Die Waffen der Völker des alten Orients. München: Kaizer.

BRENJES, $\mathrm{H}$.

1986. Kriegswesen im alten Orient. Altertum 32:133-142.

Coxon, D.

1992. Ashpenaz. ABD 1:490-491.

DALLEY, S.

1985. Foreign chariotry and cavalry in the armies of Tiglat-Pileser III and Sargon II. Iraq 47:31-48.

Dalley, S. \& Postgate, J.N.

1984. The tablets from Fort Shalmaneser. Cuneiform texts from Nineveh 3. Oxford: Oxford University.

De Graeve, M.C.

1981. The ships of the Ancient Near East (2000-500 B.C.). Orientalia Lovaniensia Analecta 7.

Doran, R.

1986. Narrative literature. In R.A. Kraft \& G.W.E. Nickelsburg (eds.), The Bible and its modern interpreters 2 (Philadelphia, PA: Fortress), pp. 287-310.

EICHLER, B.L.

1983. Of slings and shields, throw-sticks and javelins. Journal of the American Oriental Society 103:95-102.

EPH'AL, L.

1983. On warfare and military control in the Ancient Near Eastern Empire: A research outline. In: H. Tadmor \& M. Weinfeld (eds.), History, historiography and interpretation (Jerusalem: Magnes), pp. 88-106.

Evans, G.

1960. An Old Babylonian soldier. Journal of Cuneiform Studies 14:34-36.

Gaventa, B.R.

1986. From darkness to light: Aspects of conversion in the New Testament. Philadelphia: Fortress. 
Gehman, H.S.

1924. Notes on the Persian words in the Book of Esther. Journal of Biblical Literature 43:321-328.

Gesenius, W.

1953. A Hebrew and English Lexicon of the Old Testament. Tr. by E. Robinson. Oxford: Clarendon.

Goetze, A.

1963. Warfare in Asia Minor. Iraq 25:124-130.

GreENFIELD, J.C.

1981. Ahikar in the Book of Tobit. In: J. Doré, P. Grelot \& M. Carrez (eds.), De la Torah au Messie (Paris: Desdee), pp. 329-336.

Grossfeld, B.

1984. Concordance of the First Targum to the Book of Esther. Chico, CA: Scholars. SBLAS 5.

HAUPT, P.

1982. Critical notes on Esther. In: C.A. Moore (ed.), Studies in the Book of Esther (New York: Doubleday), pp. 1-79.

Herzog, C. \& Gichon, M.

1978. Battles of the Bible. London: Widenfeld and Nicolson.

HolladAY, W.L. (ED.)

1971. A concise Hebrew and Aramaic Lexicon of the Old Testament. Grand Rapids: William B. Eerdmans.

Houwink Ten Cate, P.H.J.

1983. The history of warfare according to Hittite sources: The annals of Hattusilis I. Anatolica 10:91-109.

KADISH, G.E.

1969. Eunuchs in Ancient Egypt. In: E. B. Hauser (ed.), Studies in honor of John A. Wilson (Chicago: University of Chicago), pp. 55-62.

LitTAUER, M.A.

1976. New light on the Assyrian Chariot. Orientalia (New series) 45:217-226.

LitTAuer, M.A. \& Crouwel, J.H.

1979. Wheeled vehicles and ridden animals in the Ancient Near East. Leiden: Brill.

MatTHEWS, V.H.

1981. Legal aspects of military service in Ancient Mesopotamia. Military Law Review 94:135-151.

MiLlaRd, A.R.

1977. The Persian names in Esther and the reliability of the Hebrew text. Journal of Biblical Literature 96:481-488. 
Milleer, R., McEwen, E. \& Bergman, C.

1986. Experimental approaches to Ancient Near Eastern Archery. World Archaeology 18:178-195.

MoORE, C.A.

1992. Esther. $A B D$ 2:632-643.

Moortgat, A.

1930. Der Kampf zu Wagen in der Kunst des alten Orients. Orientalistische Literaturzeitung 33:841-854.

NAGEL, W.

1966. Der mesopotamische Streitwagen und seine Entwicklung im ostmediterranen Bereich. Berlin: Walter de Gruyter.

NiDitCH, S. \& DoRan, R.

1977. The success story of the wise courtier. Journal of Biblical Literature 96:179-193.

PARPOLA, S.

1981. Assyrian royal inscriptions and Neo-Assyrian letters. In: F.M. Fales (ed.), Assyrian Royal Inscriptions: New horizons (Rome: Biblical Institute), pp. 117-134.

PAUL, S.

2002. Mesopotamian background of Daniel 1-6. In: J.J. Collins \& P.W. Flint (eds.), The Book of Daniel. Composition and reception (Boston, Leiden: Brill), Vol. 1, pp. 55-68.

Postgate, J.N.

1974. Taxation and conscription in the Assyrian Empire. Rome: Biblical Institute.

1979. The economic structure of the Assyrian Empire. In: M.T. Larsen, (ed.), Power and propaganda: A symposium on ancient empires (Copenhagen: Nederlands Historisch-Archaeologisch Instituut, Mesopotamia 7), pp. 193-221.

RAINeY, A.F.

1965. The military personnel of Ugarit. Journal of Near Eastern Studies 24:17-27.

READE, J.E.

1972. The Neo-Assyrian court and army: Evidence from the sculptures. Iraq 34:87-112.

ReEse, J.M.

1965. Plan and structure in the Book of Wisdom. CBQ 27:391-399.

Retief, F.P., Riekert, S.J.P.K. \& Cilliers, J.F.G.

2002. Eunugs in die Bybel. Acta Theologica 22:114-125.

SAGgS, H.W.

1963. Assyrian warfare in the Sargonid period. Iraq 25:145-154.

SALONEN, E.

1965. Die Waffen der alten Mesopotamier. Helsinki: Folklore Fellows. Symbolae osloenses 33.

1968. Zum altbabylonischen Kriegswesen. Bibliotheca Orientalis 25:160-162. 
SASSON, J.M.

1969. The military establishments at Mari. Rome: Editrice Pontificio Istituto Biblico. Studia Pohl 3.

SCHROEDER, O.

1920. Dokumente des assyrischen Militarismus. Orientalistische Literaturzeitung 23: 155-158.

Schulman, A.R.

1975. On the Egyptian name of Joseph: A new approach. Studien zur Altägyptischen Kultur 2:235-243.

SHERIFFS, R.J.A.

1962. Eunuch. In: J.D. Douglas (ed.). The New Bible Dictionary (Leicester: Inter-Varsity), pp. 398-399.

VAN UNNIK, W.C. 1973. Der Befehl aan Philippus. In: Sparsa Collecta 3 (Leiden: Brill), Vol. 1, pp. 328-339.

VAN DER TOORN, K. 2002. Scholars in the Oriental court: The figure of Daniel against its Mesopotamian background. In: J.J. Collins \& P.W. Flint (eds.), The Book of Daniel. Composition and reception (Boston, Leiden: Brill) Vol. 1, pp. 37-54.

Von SOdEN, W.

1963. Die Assyrer und der Krieg. Iraq 25:131-144.

WATKINS, T.

1983. Sumerian weapons, warfare and warriors. Sumer 39:100-102.

WEIDNER, E.

1956. Hof- und Harems-Erlase assyrischer Konige aus dem 2. Jahrtausend v. Chr. Archiv für Orientforschung 27:257-293.

YADIN, Y.

1963. The art of warfare in Biblical Lands. London: Weidenfeld and Nicolson.

YaMAUCHI, E.M.

1980. Was Nehemiah the cupbearer a eunuch? ZAW 92:132-142.

YOUNG, T.C.

1983. The Assyrian army on the Middle Euphrates: Evidence from current excavations. Bibliotheca Syro-Mesopotamica 56:19-32.

ZimMERMANN, R.

1966. The Book of Wisdom: Its language and character. Jewish Quarterly Review57: 1-27, 101-135. 
$\mathrm{Nel}$

Eunug in die Antieke Nabye Ooste

Trefwoorde

Antieke Nabye Ooste

Eunug

Hofamptenaar

Gekastreerde
Keywords

Ancient Near East

Eunuch

Palace official

Castrated person 